\title{
Social Justice for Women from the Perspective of their Participation in Politics - Practice of Vietnam
}

Doi:10.5901/jesr.2015.v5n1p351

\author{
Prof. Dr. Nguyen Thi Nga ${ }^{1}$
}

\begin{abstract}
Through desk review and indeep interviews with women and men leaders in Vietnam, this article argues that women's polotical participation is an essential dimemsion of social equality througth three parts. The first part examines four theoretical frameworks, which are Gender and Development (GAD), Feminism on Gender equality, human right appoach, and sustainable development approach. The second part analyzes women's political participation in Vietnam through current statistics. The article, then, deepens the current trends of women's political participation in Vietnam by identifying influencing factors, both possitive and negative factors, of the current status of Vietnamese women in politics and public administration. Toward the ends, the article provides suggestions for having more women in leadership and management possitions and further study also is proposed.
\end{abstract}

Keywords: social justice, women's political participation

\section{Research Methodology}

This article deploys two main methods. First, desk review is the core methodology of this research. It has reviewed both related books and articles related to theoretical frameworks of the topic written by international scholars and Vietnamese scholars. The research also benefits from available statistics on women's participation in current Vietnam.

The second main method is in-depth interviews with 40 men and women leaders in Vietnam, in which there are 30 women and 10 men, to identify barriers and challages for women's political participation in Vietnam. The interviewees include members and leaders from the political sphare such as the National Assembly in Vietnam, members of provincial councils at province, district and cummune levels in Vietnam. In addition, interviewees also are from middle ranking leaders in the public sectors in Vietnam from varous ministries and equalvelent sectors.

\begin{tabular}{|l|c|c|c|c|}
\hline Political or public administration & Total members interviewed & Women & Men & Age \\
\hline Political sphare & 20 & 15 & 5 & $35-55$ \\
\hline Public Administration sphare & 20 & 15 & 5 & $35-55$ \\
\hline
\end{tabular}

\section{Literature Review}

There are quite many articles, reports and books written about social equality and women's political particpation all over the world and Vietnam. However, the research only examines core readings that are very influencial in Vietnam.

Le Thi in her book on Implementation of Gender Equality and Democracy in Current Vietnam examines three areas of concerns. Her first book chapter looks at the implementation process of gender equality and democracy and the role of individuals and the state in Vietnam. The chapter provides her understanding and interpretation of the Vietname's Communist Party's social policies in ensuring the equal right of enjoying right and responsibility of the Vietnamese citizens. The chapter also argues that increasing the role of the civil society in monitoring democary is a tool in social consent and gender equality. Chapter two of her book examizes the implementation of democracy and gender equality in contemporary Vietnam. The core part of this chapter is to identify and to illustrate the role of Women in implementing and increasing grassroot democacy. The second chapter also addresses baries to girls and signle women and widown in Vietnam's families in realizing their rights, including political right. The last chapter, chapter three, highlights the roles of women in comtemporary Vietnamese society, especially that of women in participating in social sciences as academics in Vietnam.

Vo Thi Mai's book on Evaluating Gender Equality Policy Based on Evidence (2013) provides a comprehensive

${ }^{1}$ Hồ Chí Minh National Political Academy, Viet Nam. Mailbox: nguyenthinga@yahoo.com. This Article is supported by National Foundation for Science and Technology Development (NAFOSTED) 
picture of implementation of gender equality policies in contemporary. It provides an overview of gender equality policies of the Communist Party of Vietnam, the actual picture of the implementation of the mentioned policies, its outputs, challages and influencing factors to the implementing process of gender equality policy in Vietnam.

Nguyen Duc Hat in his book on Improving Leadership Capacity in Politics provides theoretical framworks on capacity building for women leaders in political sphare in Vietnam, achievement of capacity building for women in politics, and suggested ways forward to increase women's leadership capacity in politics.

In the Report Rising to the Top: Report on Women's Leadership in Asia, Astrid S. Tuminez provides insights into women's leadership in Asia, pathways to leadership positions and suggested policies and research to increase women's political representation in Asia.

Luong Thu Hien and Chau My Linh in their article on Women's participaiton in Leadership and Management in Vietnam: Achievements and Ways Foreward provides reasons for why women's poltical participation matters in Vietnam, most updated statistics on Vietnamese women's participation in national assemply, people councials at provincial, district, commune levels, women's participation in the public sectors in cluding the rate of women in ministerial, department and division levels in the administrative sphare in Vietnam. Their article also analyzes strength and weakness of Vietnam's current policies on women's political participation, influencing factors and suggested ways forward, especially the role of the Vietnam's National Center for Women in Politics and Public Administration (WiPPA) in increasing the quality and quantity of women's political participation.

Luong Thu Hien and Chau My Linh's article on Women's Participation in Leadership and Management: International Experiences and Lessons Learned suggests six actions plan to empower women's political participation including constitutional reform, party's policies, electorial reform, capacity building, gender responsive parliament, and cultural changes toward more gender equality.

\section{Thereotical Frameworks of Social Equality and Women's Politica Participation}

This article argues that women's political participaiton is an essential factor of social equality. Social equality is a deep desire, the ideals that the country in today's society towards. To build an equitable society can not ignore issues of social justice for women. Many approaches have shown that women's ability to take part in politics is one of the basic signs of social justice for women. Therefore, strengthening the political participation of women is one of the objectives to be reached in the process of implementing social justice. Our article tries to find out the situation of women taking part in politics in Vietnam, causes and lessons learned from this situation.

On 11/26/2007, in the 62th session, the UN General Assembly adopted the "Resolution 62/10," the decision taken the day February 20 every year, starting from 2009 as "World Day of Social Justice". This shows the importance of the issue. In Vietnam today, implementing issues of social justice is a goal of the new society has been confirmed in many important documents of the Communist Party and the State.

Social justice is a historical problem, always changes in history and in reality it is usually achieved at certain levels, depending on the target as well as the specific conditions of each people, each nation, and each given historical period. In Vietnam, there are also many different opinions on this issue ${ }^{2}$. However, the basic connotation of social justice can be understood as treating people equally according to their contribution; treat people in appropriate ways according to their inborn differences or different social conditions (due to occupational differences, differences in education and training, in inheritance and properties, and differences in risks incurred). Besides, social justice will have to cover the equity in the distribution of opportunities and conditions for implementation of opportunities. Currently, in Vietnam, implementation of social justice is understood as the effective implementation of issues such as fairness in opportunities, fairness in sharing responsibility, fairness in the enjoyment of basic rights such as freedom and justice, based on communitarianism and intergenerational justice. This will help to ensure sustainable development in many different aspects.

Women's political participation is an important level in the awareness and implementation of social justice for women today. In Vietnam, there are several basic approaches to this issue:

- From the viewpoint of Gender and development (GAD), to enhance the role of gender equality: women and men should be treated equally in order to achieve gender equality. This perspective requires considering and solving problems involving sex with the participation of both women and men in all aspects of development including economics, education, politics and health.

2 View Prof. Dr. Le Huu Tang, "Some theoretical issues and practices surrounding the implementation of social justice in today's Vietnam", Journal of Philosophy, http // www.triethoc.com.vn, Date: 8 / 5/2008 and Dr. Nguyen Minh Tuan's discussion of social justice, Tia sang Journal 04/09/2013. 
- From the feminist perspective that the secondary status of women is broadly derived from the injustice that women suffered in patriarchal societies throughout a long history in both the East and the West. Feminism as a social movement of women struggles to expand and protect the rights of women and eliminate patriarchy on a global scale. Feminist analysis is about the differences between men and women which prove that men cannot represent women in society and science. It is also about building solidarity and interaction between the sexes to eliminate opposition, exploitation and domination. The goal of feminism is to build a humane, fair, equal and civilized society ${ }^{3}$.

- From human rights perspective that women's political participation reveals equality and justice for women from the political angle. The spirit underlying this was confirmed by Vietnam's leaders as well as in many important legal documents. Regarding this viewpoint, there is a perception that since women account for $50 \%$ of the population, their representatives in leadership, management should reflect the same proportion in comparison with men's representatives.

- Approaching from the standpoint of sustainable development, it is said that more involvement of women in parliament could contribute to the sustainable development of the country. There are studies showing that there is a proportional relation between gender equality, the empowerment of women and justice, sustainability, poverty reduction and environmental protection ${ }^{4}$.

With the above basic approaches, in Vietnam and many other countries, women's participation in leadership and management is one of the basic signs, a ladder needed for social justice for women to become more probably real because of the following reasons:

Women make up half the world's population, so they absolutely have the right to hold $50 \%$ of the positions of decision-making power. There is no legitimate reason to prevent qualified women from having a desire to hold an important position in the political system of any country.

Women's political participation is also a sign of social justice since recognizing the position, role and capacity of women in leadership and management means that society has created equality for woman in dedication and enjoyment according to their ability in all areas of social life including politics. This also means that men - half the world's remaining, initially admit the truth that women should be treated fairly and equally to men.

The higher the number of women participating in politics is, the more opportunities for reflecting the needs, interests and life experiences characterized by gender difference in the process of planning and policy making in each country. From here, women have more and more opportunities to attain fairness and equality for themselves.

For the reasons discussed above, we absolutely have the right to confirm that the increase of women's involvement in politics is one of the basic signs of social justice for women. The participation of women in politics is not simply to bring equality to women in this field but also the conditions and prerequisites for solving problems of social justice for women in many other aspects.

Women cannot be completely liberated and cannot really be equal if they only achieve equality in socio-economic field, not in political field. Moreover achieving equality in political field is a condition for women to be able to liberate themselves in other fields. If women have economic strength without the legal representative in politics, it will be very difficult for them to raise their voice, expressing their desire, needs, and specific benefits of their own.

With analysis pointed out above, it is possible to draw an objective conclusion that the political participation of women and the enhancement of this process is a ladder in the struggle for social justice for women. This is particularly significant in Asian countries which have experienced feudalism with the dominance of Confucian ideology, including Vietnam.

In Vietnam, Ho Chi Minh is one of the first leaders who asserted women's liberation in politics is a major content of the liberation of women in general. The explanation, women's liberation must be associated with liberation, class liberation. Women's liberation is a part of national liberation. Only when the country is liberated, can women escape from slavery and have equal rights with men in the implementation of civil rights, in election in political system.

\footnotetext{
${ }^{3}$ See more: Prof. Le Thi Quy: "The theory and the feminist", in research project: Feminist philosophy as a philosophical theory of social justice for women, code: 11.7- 2011.25, sponsored by the National Fund for Development of Science and Technology (NAFOSTED) by Prof. Dr. Nguyen Thi Nga (homeroom).

${ }^{4}$ See more: Astrid S.Tuminez, "Reaching the summit", Leaders report on women in Asia, page 15. According to the report of the World Bank (World Development Report 2006 - Equity and Development), in countries in which the elements of justice, especially in terms of opportunities (Equality of opportunity) are perceived and defended, those countries will attain good economic growth. (See the report of the World Bank (World Bank) on the fairness and Development (Equity and Development) in 2006 at the address: http://econ.worldbank.org/external/default/main?pagePK=64165259\&theSitePK=478060\&piPK=64165421\&menuPK=64166093\&entity 
It can also be seen as the highlights of Ho Chi Minh's ideas of women's liberation. Because the idea of the equal rights, justice for women in other fields such as economics, literature, art ... of former thinkers, writers, poets is not uncommon. However, the idea of women's liberation, equal rights for women in the political field is really clear in Ho Chi Minh's thought. From the fact that women in the feudal society have suffered injustice in various fields, especially in the field of politics, Ho Chi Minh's ideas confirmed its great significance. Reality shows that when women attain their liberation in politics, they can also liberate themselves in other fields. With this meaning, women's participation in politics is not just a ladder of progression but also a tremendous step forward in the cause of liberating and bringing social justice for women in countries like Vietnam. This is the result of a long and arduous struggle of Vietnamese women in particular and the Communist Party and the State of Vietnam as well as of the whole society in general.

Women taking part in leadership, management may contribute to social progress. Through the role of women in leadership and management we can evaluate the level of empowerment of women and the role of women in politics through different development periods.

\section{Women's Political Participaiton In Vietnam}

For the case of Vietnam, with the approaches above, Vietnam has made many achievements in gender equality in various fields such as education, healthcare, etc. However, from the aspect of women's political participation, the actual results are still not as satisfied as expected.

Current status of Vietnamese women's political participation in this article is judged according to the basic indicators such as the rate of women in National Assembly and People's Council at all levels, the proportion of female managers at all levels. The leadership and management of women in Vietnam are represented by the specific numbers below:

\subsection{The number and percentage of female deputies}

Figure: Percentage of women in parliament according to terms ${ }^{5}$

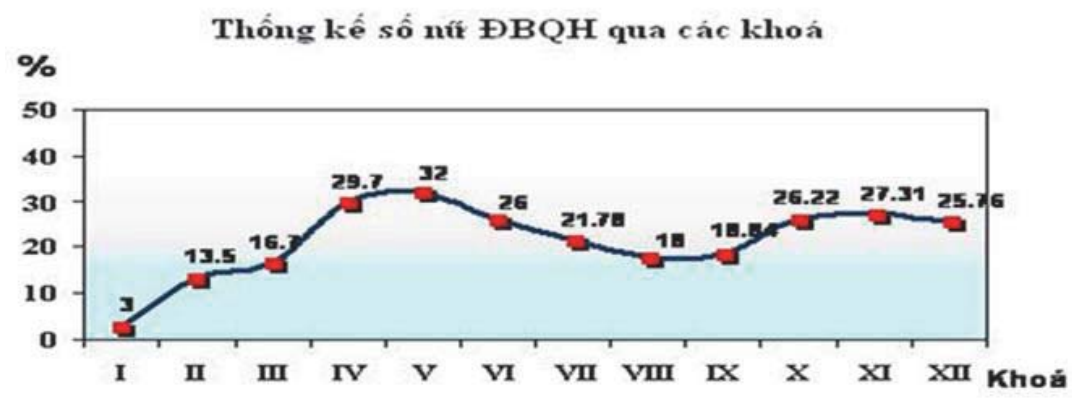

Charts and tables indicate that, in National Assembly (from I to XII tenure), the $5^{\text {th }}$ National Assembly had the highest percentage of female deputies with $32.3 \%$. The percentage of female deputies in National Assembly (tenure XIII) is $24.4 \%$ and ranks $43 / 143$ countries in the world. Overall, in recent years, Vietnam is one of the few countries in the Asia Pacific region with the proportion of female deputies at over $25 \%$. The number of women holding important positions in Congressional offices has increased in recent time. However, in 9 consecutive parliamentary tenures (from V to XIII tenure), this ratio tends to decrease and creates horizontal line. This tendency proves the difficulty in the implementation of justice and equality for women in the National Assembly in Vietnam.

5 The data on female parliamentarians, Statistics on the number of female deputies keywords I to XII, http://www.na.gov.vn, updated on 09/05/2014. 


\subsection{Women participate in the Party Central Committee 6}

Table: Women participating in the Party Central Committee

\begin{tabular}{|c|l|c|c|c|c|}
\hline \multirow{2}{*}{ No } & \multirow{2}{*}{ List } & \multicolumn{2}{|c|}{ X (2006-2010) } & \multicolumn{2}{c|}{ XI (2011-2015) } \\
\cline { 3 - 5 } & Female (people) & Percentage (\%) & Female (people) & Percentage (\%) \\
\hline 1 & Member of the Politburo & & & 2 & 9.14 \\
\hline 2 & Secretary of the Party Central & 1 & 12.5 & 2 & 20 \\
\hline 3 & Member of Executive Committee (official) & 13 & 8.13 & 15 & 8.57 \\
\hline 4 & Member of Executive Committee (alternate) & 3 & 14.29 & 3 & 12 \\
\hline
\end{tabular}

\subsection{The number of People's Councils at all levels}

The percentage of women participating in the People's Council of provinces and large cities during 2011-2016 tenure is 25.17\%; in the People's Council of districts and towns is 24.62\%; in the People's Councils of communes, wards and towns is $21.71 \%$. The percentage of women holding the office of Chairman of the People's Council at provincial level is $4.76 \%$ (up 3.2\% over the 2004-2009 tenure, at district level is 6\% (up 2. 1\%); at commune level is 5.67\% (up 1.58\%) and the ratio of female Deputy Chairman of the People's Council at provincial level is $19.05 \%$ (down $7.51 \%$ ), at district level is 14 , 09\% (down 5.55\%); at commune level is $13.06 \%$ (up 3\%). Remarkably, it was the first time Vietnam had two Politburo members are women?.

In short, the number of female leaders in the State and other organizations is still low. National Strategy for the Advancement of Women in 2020 and the millennium goals of Vietnam has set targets to increase the proportion of female deputies to $30 \%$, female deputies of the People's Councils at all levels to achieve $28-30 \%$. In fact, the percentage of women deputies to the National Assembly during the $2011-2016$ period is $24.4 \%$, do not achieve the set targets. The proportion of women in the People's Councils at the provincial level in 2011-2016 period is 25.70\%, at district level is $24.62 \%$ and commune level is $27.71 \%$, well do not achieve the targets above ${ }^{8}$.

\subsection{The proportion of women in the Party committees ${ }^{9}$}

Table: Percentage of women in the party committees (\%)

\begin{tabular}{|l|l|c|c|c|c|c|c|}
\hline \multirow{2}{*}{ No } & \multirow{2}{*}{ Position } & \multicolumn{3}{|c|}{ tenure (2006-2010) } & \multicolumn{3}{c|}{ tenure (2011-2015) } \\
\cline { 3 - 8 } & $\begin{array}{c}\text { Province } \\
\text { Level }\end{array}$ & $\begin{array}{c}\text { District } \\
\text { Level }\end{array}$ & $\begin{array}{c}\text { Commune } \\
\text { Level }\end{array}$ & $\begin{array}{c}\text { Province } \\
\text { Level }\end{array}$ & $\begin{array}{c}\text { District } \\
\text { Level }\end{array}$ & $\begin{array}{c}\text { Commune } \\
\text { Level }\end{array}$ \\
\hline 1 & Secretary & 6.25 & 4.46 & 4.59 & 3.17 & 4.77 & 6.18 \\
\hline 2 & Deputy Secretary & 3.88 & 5.54 & 7.25 & 9.52 & 5.82 & 8.42 \\
\hline 3 & Member of the Standing Committee & 7.91 & 7.83 & 5.83 & 8.25 & 10.19 & 9.10 \\
\hline 4 & Member of the Executive Committee & 11.75 & 14.74 & 14.36 & 11.30 & 15.16 & 18 \\
\hline
\end{tabular}

The table above indicates that the percentage of women participating in Executive Committees and Standing Committees during 2006 -2010 and 2011-2015 periods has generally increased. In particular, at the commune/ ward level the proportion of women in the Standing Committee is high and grows rapidly. However, at all three levels deputy secretary female ratio has increased but the number is still low. In the secretary position the number is low, even at provincial level the number is reduced.

\footnotetext{
6 Source: Office of the Party Central Committee, 2011.

${ }^{7}$ Nguyen Thanh Hoa, Deputy Minister of Labour, Invalids and Social Affairs, "Measures to enhance the role of women in sustainable development", www.molisa.gov.vn. In 2014, the number of members of the Politburo increases compared to 2011 due to additional election.

8 National Strategy on Gender Equality 2011-2020. Goal 1, Indicator 3, National Strategy on Gender Equality 2011-2020.

9 Source: Central Organizing Committee (2006), the Central Office of the Party (2011).
} 


\subsection{Percentage of women in leadership and management of central government}

Table: Percentage of women in leadership and management of central government $(\%)^{10}$

\begin{tabular}{|c|l|c|c|c|c|}
\hline \multirow{2}{*}{ No } & \multirow{2}{*}{ Position } & \multicolumn{2}{|c|}{ Năm 2007 } & \multicolumn{2}{c|}{ catalog 12-2011 } \\
\cline { 3 - 6 } & & Female & Proportion & Female & Proportion \\
\hline 1 & Vice President & 1 & 100 & 1 & 100 \\
\hline 2 & Ministers and equivalent & 1 & 4.5 & 2 & 9.09 \\
\hline 3 & Deputy minister and equivalent & 9 & 8.4 & 11 & 8.27 \\
\hline 4 & Director and equivalent & 61 & 8.11 & 54 & 9.73 \\
\hline 5 & Deputy Director and equivalent & 240 & 14.94 & 287 & 19.04 \\
\hline
\end{tabular}

The summary table above shows that women hold ministerial positions and equivalents (May 12-2011) is 2 out of 22, accounting for $9.09 \%$, by 2014 this figure has remained unchanged (4.5\% increase compared to 2007). According to the Inter-Parliamentary Union, in Jan, 2014, the proportion of women holding director positions and equivalent in 189 countries is $17.2 \%$ (compared to $16.1 \%$ in 2008). The proportion of deputy minister position is also low, in some ministries still not have women leaders.

\subsection{Rate of female leaders at all levels and sectors ${ }^{11}$}

Chart: Percentage of management leadership by gender, 2007-201012 / Proportion of Leaders by sex, 2007-2010 (\%)

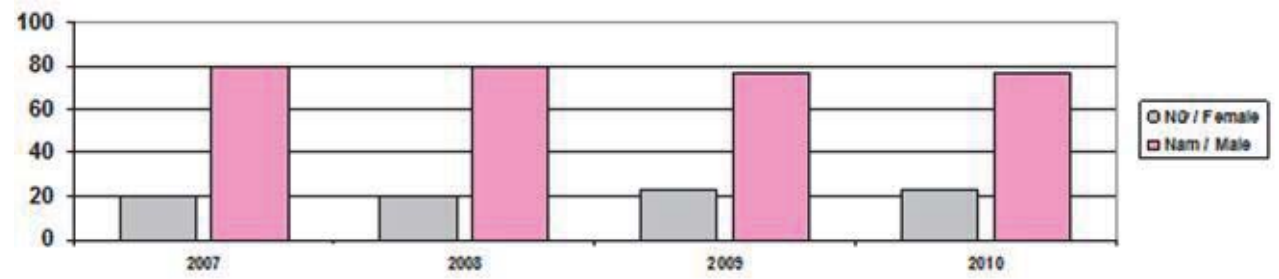

Rate of female leaders at all levels in 2010 is $23.3 \%$. Compared to the $2007-2010$ period it tends to increase slightly, from $20.5 \%$ to $23.3 \%$. However, compared to men, this rate is much lower now, namely, $1 / 4$ (Figure 4).

The above figures show that, in Vietnam today, Vietnamese women have the opportunity to participate in social management and leadership at all levels. Social justice tendency from the aspect of political opportunities has opened up. Hence, it could be said that Vietnam belongs to the group of countries which has the increasing proportion of women leaders at all levels. However, the higher the positions are, the lower the proportion of female cadres is. Moreover, the increase rate is slow, many specific targets of the strategy of Vietnam are difficult to achieve in practice.

\section{Part Five: Ways Forward}

In search of the causes of this situation, many studies have shown that the institutional framework covering the entire political system ${ }^{13}$ is an important factor. During the process of building a new society, the Party and State of Vietnam have paid special attention to creating opportunities for human development as well as promoting the human factor, without discrimination of basic human rights between men and women. The 1946 Constitution, the first Constitution of Modern Vietnam, has recognized "women are equal to men in all respects." This spirit continued to be asserted in the amended constitution and was later reflected in other legal documents. In 1981, Vietnam joined the United Nations Convention on the Elimination of All Forms of Discrimination Against Women (CEDAW). This spirit is also conveyed

10 Vietnam Women's Union Yearbook compiled by the National Assembly, the Government (tenure XIII), the People's Council, People's Committee 2011-2016 period (2012).

11 Leaders of levels of Party Leaders and Agencies include, National Assembly, Government, People's Court, People's Councils, People's Committee, unions, organizations, humanitarian groups, other groups, companies, enterprises, schools.

12 Source: GSO Labour Force Surveys and Employment 2007-2010 / GSO, Labour Force and Employment Survey 2007-2010

13 View Thu Hien Luong American Spirit, Enhancing Participation of Women: Status and contempt of experience in Asia Pacific countries, Journal of Ethnic and \& Times, July + 8-2014 
specifically in other important documents such as Gender Equality Law, "National Strategy for the Advancement of Women in Vietnam to 2010", "National Strategy on Gender Equality 2011-2020", etc. The Constitution amended by the National Assembly on November 28, 2013 reaffirmed this view. Article 26 of the Constitution clearly stated:

1. Male and female citizens are equal in all respects. The State implements policies to ensure equal rights and opportunities for men and women.

2. State, society and families facilitate the comprehensive development and roles of women in the society.

3. Gender discrimination is strictly prohibited.

This legal basis is crucially important, paving the way for a new trend of development and human liberation, which includes both men and women. It is also an important legal premise contributing to the effective implementation of gender equality target in Vietnam. However, the institutional and legal environment is insufficient to obtain the desired change, because the change in perception and behavior of human beings, of the community depends on many other factors. Studies in the field show that in Vietnam, there are many challenges facing women in their career which can be listed here: the impact of the head of the organization; cultural norms, gender-biased customs; little chance of changing job, of training compared with men; the legal framework and public policy have different treatment between men and women ...

Analysis of policies shows that some specific provisions do not agree with the general principles. Regulations on appointment age could be seen as typical example. Regulations on the appointment, reappointment, rotation, resignation and dismissal of cadres and leaders states: "Officers and employees are appointed for the first time not exceeding 55 years for men and no more than 50 years for women"14. These rules, for whatever reasons, have limited opportunities, causing more difficulties in promotion and appointment for women than men, although they have basically the same capacity. Moreover, the retirement age of men and women also differs (60 men and 55 women). This is an obstacle for women in their career. Some evidences show that the common goals have encouraging value but the specific measures to deal with cases are still not strong enough to reach those goals.

From a traditional perspective of cultural customs, it is shown that Vietnam and many other Asian countries experienced feudalism in a long time are deeply influenced by Confucian ideology. One of the basic characteristics of Confucian doctrine is patriarchalism which respects men and looks down on women. Confucianism has used system of ethics as "Three Obediences", "Four Virtues", "women cannot be educated", etc. to bind and constrain the development of women. According to Confucianism, women must hold fast to "Three Obediences", "Four Virtues"15. It requires women to respect men and depend on them. This is the invisible thread binding the women and they are limited behind the family's door. In feudal society, women's only obligation is to obey the men in the family and their sole responsibility is to take care of the family so that the men can participate in the political and social activities. That means the women have absolutely no right to keep their positions in the political system of feudal dynasties and have no right to participate in any national work. Social justice for women in the Confucian notion seems to be nothing.

Confucius also says "women cannot be educated". It means that it is so difficult to teach a woman. With this concept, Confucianism has removed the woman from education, not give them a chance to realize their potential and assert their role in the development of society. This is actually the elimination of creativity and contributions of women as well as the cause of the stagnation of the feudal society in its thousands-of-years history.

Vietnam feudal society, for centuries, is deeply influenced by Confucianism. This stereotype has dominated political institutions, social norms, the rules of ethics, the content of education, etc. and people of Vietnam through generations have suffered from the negative influence of Confucianism. This fact has deepened the gender bias, even subconsciously ingrained that individuals themselves do not recognize. The research using interview method as well as observing the behavior of individuals in the community in Vietnam shows that gender-biased stereotypes exist not only in men but also in women, not just ordinary people but also managers and leaders. These stereotypes imply that the duty of woman is caring for the family and that men have higher capacity than women.

In addition to the external barriers, women in Vietnam still have a tendency for self-bias and underestimate themselves. Many women interviewed show no motivation and do not want to openly express their thoughts and desires in management and leadership.

${ }_{14}$ Regulations on the appointment, reappointment, rotation, resignation and dismissal of cadres and leaders (Issued together with Decision No. 27/2003 / QD-TTg. On 19 May 02, 2003, the Prime Minister)

${ }^{15}$ Confucian concept of "Three Obediences" is: obey her father as a daughter, obey her husband as a wife, obey her son in widowhood. The concept of "four virtues" Confucian includes: morality, proper speech, appearance, diligent work. According to these concepts, the women have to sacrifice all the benefits, needs, personal desires to tame the men in their lives (father, husband, son). 
To promote the participation of women in leadership management in Vietnam today, the removal of barriers is crucially the key to emancipate the potential of women as an important contributor to achieve the objectives of development: wealthy people, a strong nation and an equal, democratic society. The struggle for women's liberation, implementing social justice for women, enhancing the political participation of women is the cause of the whole society, but first the cause of women themselves. The second-class status of women and the inequality of opportunity for women in history are not permanent. In order to remove these obstacles, on the one hand we have to change social relations, social prejudice and build properly political institutions, legal framework consistent progress; on the other hand we have to change the perspective and psychology of women as well as their own actions. They themselves must overcome themselves and meet the requirements of modern society, contributing to the development of society. The goal of social justice for women is not just for women but for the sustainable development of nations and peoples in the twenty-first century. This goal can not be attained without interest and positive support of men. The change in the gender bias in men's actions in their particular family as well as in society is a necessary condition for social justice for women. Social justice for women is a new level in awareness and implementation of social justice today. The activeness and positiveness of social institutions, social management and leadership subjects play an important role in this cause. Changing the perception as well as behaviors which are unfair to women requires a drastic reform in leadership, social management to guide and orientate the whole society./.

\section{References}

Astrid S.Tuminez. (2012). Rising to the Top: Women's Leadership in Asia (Vươn tới đỉnh cao. Báo cáo về lãnh đạo nữ ở Châu Á) , p. 15. Asia Society (Báo cáo được giới thiệu lần đầu tiên bằng tiếng Anh và được Trường Lý Quang Diệu và Hội Châu Á bắt đầu quảng bá ngày 19/04/2012.

Electric Newspaper, Statisitics on women Deputies from term I to term XII (Báo điện tử . 2014. Thống kê về số lượng nữ đại biểu Quốc hội tưr khóa I đến khóa XII), http://www.na.gov.vn, last accessed on 5/9/2014.

National Strategy on Gender Equality 2011 - 2020 (Chiến lược quốc gia về Bình đẳng giới 2011-2020.) Goal 1, Indicator 3, National Strategy on Gender Equality 2011-2020 (the approval of Prime Minister on the National Strategy of gender equality, 2351 QD-TTD 24/12/ 2010 (quoted from http/www.chinhphu.vn)

Lương Thu Hiền- Châu Mỹ Linh, Empowerment of Vietnamese Women's Political Participation: Reality and Ways forward. Journal Dân Tộc và\& Thời Đại, No 6, 2014

Lương Thu Hiền- Châu Mỹ Linh, Empowerment of Women's Political Participation: Reality and Lessons Learned from Asia Countries (Tăng cường sự tham chính của phụ nữ: Thực trạng và khinh nghiệm của các nước Châu Á- Thái Bình Dương) , Journal Dân Tộc và\& Thời Đại, No 7+8, 2014

Nguyễn Thanh Hòa. Solutions to empower the Role of Women in Sustainable Development (Giải pháp nâng cao vai trò của phụ nữ trong phát triển bền vững). http:/l.www.molisa.gov.vn.

Võ Thị Mai (2013). Evaluating Gender Equality Policies Based on Evidence (Đánh giá chính sách bình đẳng giới dựa trên bằng chứng). Nxb Chính trị Quốc gia - Sự thật. Hà Nội.

Nguyen Thi Nga, Ongoing Implementation of Social Equality for Women in Current Vietnam, Journal Communist Party of Vietnam, No. 89 (5 2014) pp. $49-54$

Lê Thị Quý: "Theoretical Frameworks and School of Feminism" ("Các lý thuyết và trường phái nữ quyền"), article from the NAFOSTED's naitonal research on Feminist Philosophy as a Philosophical Framework on Social Equality for Women lead by Prof. Nguyen Thi Nga ( bài viết trong khuôn khổ đề tài Triết học nữ quyền với tư cách là lý thuyết triết học về công bằng xã hội cho phụ nữ, mã số: 11.72011.25, được tài trợ bởi Qưi Phát triển Khoa học và Công nghệ Quốc gia (Nafosted) do PGS,TS Nguyễn Thị Nga làm chủ nhiệm.

Lê Hữu Tầng, Several Issues on Theory and Practice of Realizing Social Equality in Vietnam (Một số vấn đề lý luạn và thực tiễn xung quanh việc thực hiện công bằng xã hội ơ Việt Nam hiện nay), Journal Philosophy (Tạp chí Triết học), http//www.triethoc.com.vn, ngày 8/5/2008

Lê Thi (2011). Implementation of Gender Equality and Democracy in Current Vietnam (Vài nét bàn về việc thực thi công bằng, dân chủ và bình đẳng nam nữ ở Việt Nam hiện nay.) Nxb Khoa học xã hội. Hà Nội.

Prime Minister (Thủ tướng). (2003). Rule on Appointment, Reappointment, rotation of leaders in Vietnam (Qui chế bổ nhiệm, bổ nhiệm lại, luân chuyển, từ chức, miễn nhiệm cán bộ, công chức lãnh đạo) (Ban hành kèm theo Quyết định số 27/2003/QĐ-TTg ngày 19 tháng 02 năm 2003 của Thủ tướng Chính phủ).

Prime Ministry (Thủ tướng) (2011). Decision on approving National Strategy on Gender Equality 2011 - 2020 (Quyết định phê duyệt chương trình quốc gia về bình đẳng giới giai đoạn 2011 - 2015. Quyết định số 1241/QĐ-TTg ngày 22/7/2011.)

Nguyễn Minh Tuấn. (2013). Discussion on Social Equality (Luân bàn về công băng xã họi), Tạp chí Tia sáng 4/9/2013

UNDP - Mofa. (2012). Women Deputy: Ways Forward (Báo cáo Nữ đại biểu quốc hội ở Việt Nam hướng tới tương lai). Women's Leadership Programme (Chương trình lãnh đạo nữ Cambridge - Viet) Nam Nâng cao năng lực lãnh đạo cho phụ nữ trong khu vực nhà nước trong bối cảnh hội nhập kinh tế quốc tế.

Institute of Family and Gender (Viện Gia đình và Giới). (2009). Quanlitative Findings on Women's Leadership in the Public Sector in Vietnam (Kết quả nghiên cứu định tính về nữ lãnh đạo khu vực Nhà nước ở Việt Nam), 2009.

World Bank. (2006). World Development Report 2006 - Equity and Development. <http://econ.worldbank.org/external/default/ main?pagePK=64165259\&theSitePK=478060\&piPK=64165421\&menuPK=64166093\&entitylD=000112742_20050920110826>. 